\title{
Genetic Reconstruction of Dopamine D1 Receptor Signaling in the Nucleus Accumbens Facilitates Natural and Drug Reward Responses
}

\author{
Bryan B. Gore and Larry S. Zweifel \\ Department of Pharmacology and Department of Psychiatry and Behavioral Sciences, University of Washington, Seattle, Washington 98053
}

The dopamine D1 receptor (D1R) facilitates reward acquisition and its alteration leads to profound learning deficits. However, its minimal functional circuit requirement is unknown. Using conditional reconstruction of functional D1R signaling in D1R knock-out mice, we define distinct requirements of D1R in subregions of the nucleus accumbens (NAc) for specific dimensions of reward. We demonstrate that D1R expression in the core region of the $\mathrm{NAc}\left(\mathrm{NAc}{ }^{\mathrm{Core}}\right)$, but not the shell ( $\mathrm{NAc}{ }^{\text {Shell }}$ ), enhances selectively a unique form of pavlovian conditioned approach and mediates D1R-dependent cocaine sensitization. However, D1R expression in either the NAc Core or the $\mathrm{NAc}^{\text {Shell }}$ improves instrumental responding for reward. In contrast, neither NAc ${ }^{\text {Core }}$ nor NAc ${ }^{\text {Shell }}$ D1R is sufficient to promote motivation to work for reward in a progressive ratio task or for motor learning. These results highlight dissociated circuit requirements of D1R for dopamine-dependent behaviors.

\section{Introduction}

Differential gene expression within discrete brain regions expands neural coding capacity and diversifies circuit function. This is exemplified in the striatum, where two parallel circuits, the direct and indirect pathway, oppositely regulate thalamocortical loops. These pathways possess a similar neuronal cell type, the medium spiny neuron, yet differ dramatically in connectivity, neuropeptide expression, and genetic profiles. The balance of circuit activation between the direct and indirect pathway is necessary for numerous behaviors, including reward processing (Lobo et al., 2010, Beutler et al., 2011). The dopamine D1 receptor (D1R), encoded by the Drdla gene, is highly enriched in the direct pathway (Fig. $1 A, B$ ), where it facilitates numerous dopamine-dependent functions including appetitive behaviors. Global loss of D1R demonstrates its importance from feeding and reward acquisition to the general ability to thrive (Drago et al., 1994, Xu et al., 1994, Wall et al., 2011). A major unresolved question about genes with pleiotropic functions, such as Drd1a, is whether a minimal circuit requirement exists for specific behaviors.

Both genetic and pharmacological studies have investigated the necessity of D1R signaling in different brain regions for ac-

\footnotetext{
Received Nov. 30, 2012; revised April 4, 2013; accepted April 6, 2013.

Author contributions: B.B.G. and L.S.Z. designed research; B.B.G. and L.S.Z. performed research; B.B.G. and L.S.Z. contributed unpublished reagents/analytic tools; B.B.G. and L.S.Z. analyzed data; B.B.G. and L.S.Z. wrote the paper.

This work was supported by the National Institutes of Health (Grant R01MH094536 to L.S.Z. and Grant T32DA7278 to B.B.G.). We thank Dr. Richard Palmiter for generously providing Drd1a ${ }^{\text {Cre }}$ mice, Dr. Ali Güler for assistance with locomotion and sensitization experiments, and all members of the Zweifel laboratory for their support and critical reading of the manuscript.

The authors declare no competing financial interests.

Correspondence should be addressed to Larry S. Zweifel, 1959 NE Pacific Street, Box 357280, Seattle, WA 98195. E-mail: larryz@u.washington.edu.

DOI:10.1523/JNEUROSCI.5532-12.2013

Copyright $\odot 2013$ the authors $\quad 0270-6474 / 13 / 338640-10 \$ 15.00 / 0$
}

quisition of rewards (Yin et al., 2008, Wall et al., 2011, Salamone et al., 2012). Genetic D1R inactivation in mice demonstrated that, despite hyperactivity, these animals show poor motivation to perform instrumental tasks and lack basic pavlovian learning, which illustrates that D1R signaling is necessary somewhere within the brain (Wall et al., 2011). Pharmacological studies narrowed the potential candidate brain regions necessary for reward processing. Infusion of D1R antagonists individually into the prefrontal cortex (Baldwin et al., 2002), dorsal striatum (Lovinger, 2010), amygdala (Berglind et al., 2006, Tye et al., 2010), or nucleus accumbens (NAc; Smith-Roe and Kelley, 2000) disrupts certain aspects of reward. However, whether any of these brain regions is minimally required for different dimensions of reward is unresolved.

One caveat to locally infusing antagonists to establish regional importance of receptor function is the potential of inactivating both postsynaptic and presynaptic receptors. In comparison, conditional gene inactivation provides cell selectivity, but does not typically permit regional selectivity, nor does it exclude necessary roles for the gene in other cells/regions. Alternatively, knock-out mice are operationally a blank slate for a specific gene of interest, so conditional, anatomically restricted restoration to neurons endogenously expressing the gene can test its minimal circuit requirement. Here we developed a model system for global D1R inactivation and cell-selective, regional restoration to investigate whether D1R activation in either the core (NAc ${ }^{\text {Core }}$ ) or the shell (NAc ${ }^{\text {Shell }}$ ) region of the NAc is the minimal requisite to mediate distinct aspects of reward. We found that exclusive expression of D1R in the NAc ${ }^{\text {Core }}$ of D1R knock-out mice promoted a pavlovian conditioned approach and facilitated behavioral sensitization to repeated cocaine administration, thus highlighting the essential role of this brain region for both natural and drug rewards. In contrast, NAc ${ }^{\text {Shell }} \mathrm{D} 1 \mathrm{R}$ expression did not 
A

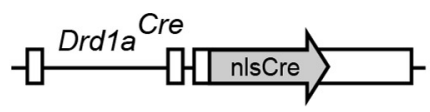

B

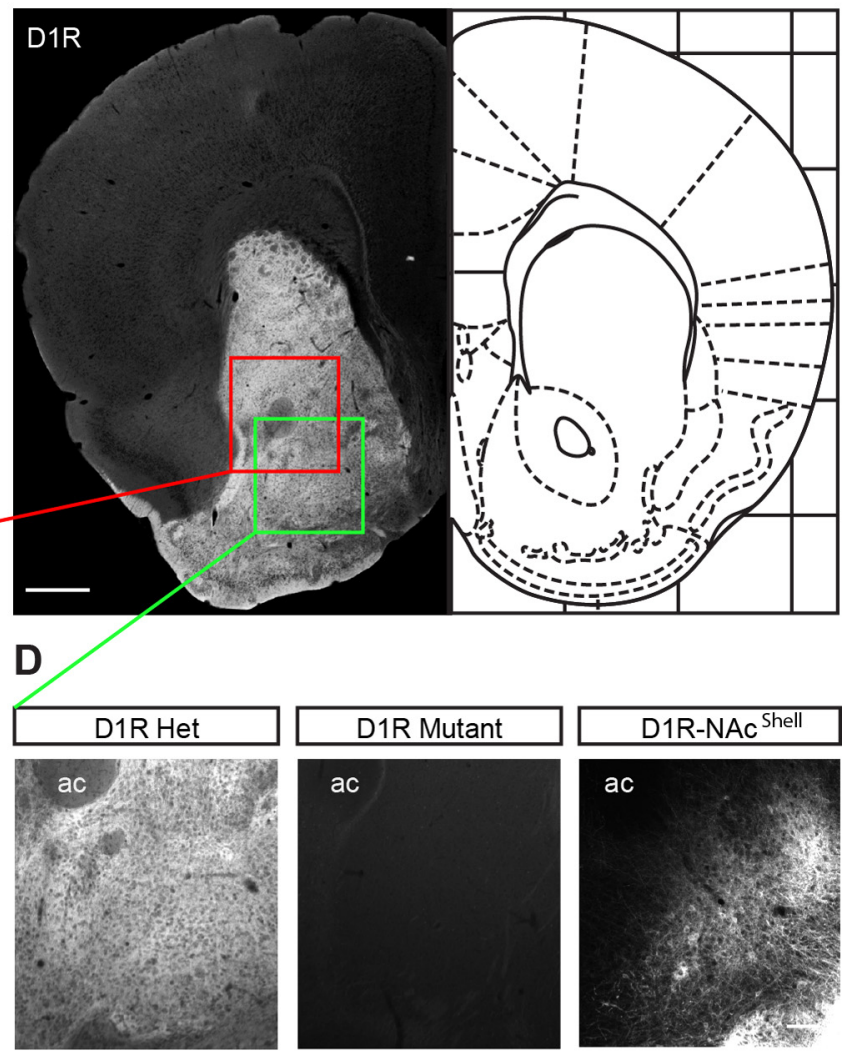

E
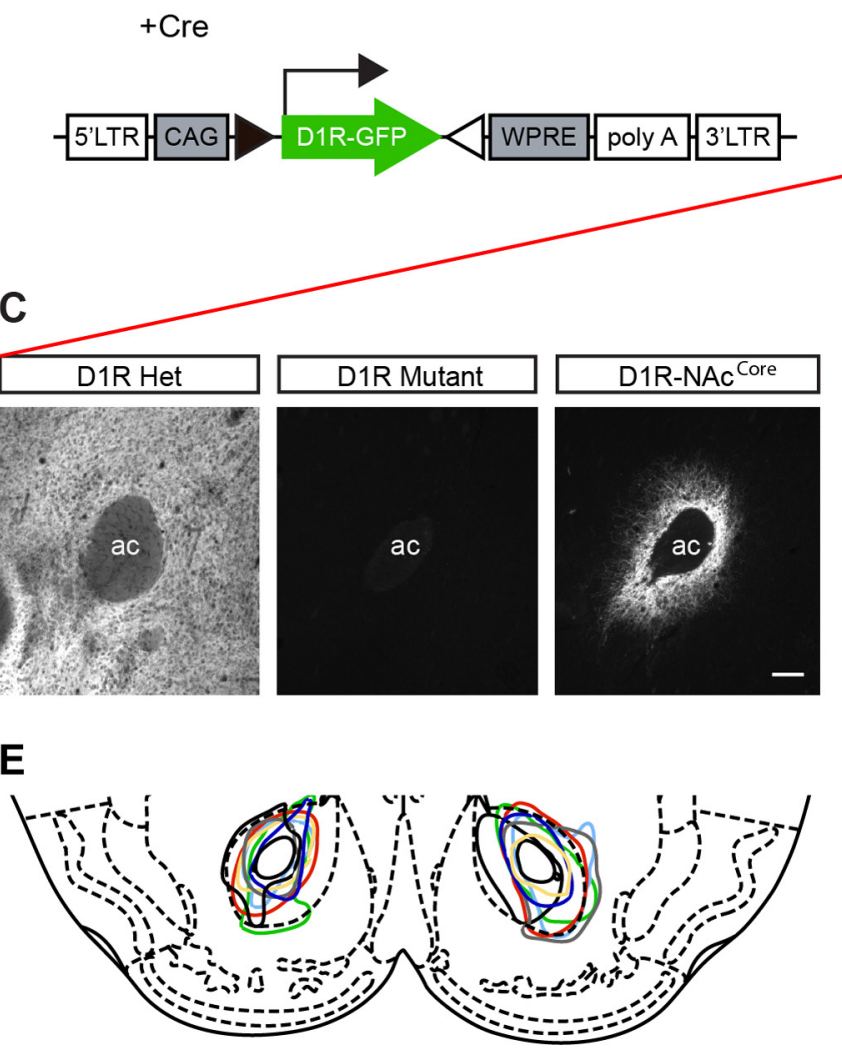

$\mathbf{F}$

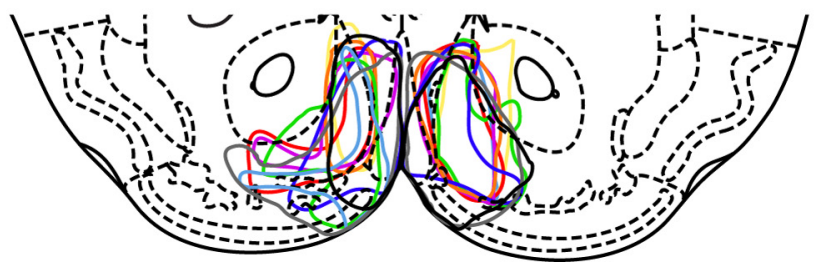

Figure 1. Conditional viral restoration of D1R expression in either the NAC ${ }^{\text {Core }}$ or the NAC ${ }^{\text {Shell }}$. $A$, Schematic representation of Drd1 ${ }^{\text {Cre }}$ allele and AAV-FLEX-D1RGFP construct. $\boldsymbol{B}$, Left, D1R protein expression is highly enriched in the striatum. Right, mouse brain atlas, bregma +1.34 (Franklin and Paxinos, 2007). C, Higher magnification of NAC ${ }^{C o r e}$ region from $\boldsymbol{B}$. D1R is completely absent in D1R mutants, but selectively expressed in the NAC ${ }^{\text {Core }}$ with AAV-FLEX-D1RGFP. D, Higher magnification of NAc shell region from B. D1R is completely absent in D1R mutants, but selectively expressed in the NAC ${ }^{\text {Shell }}$ with AAV-FLEX-D1RGFP. E, $\boldsymbol{F}$, Tracing of bilateral D1RGFP expression in D1R-NAC ${ }^{\text {Core }}(n=7)$ and D1R-NAC ${ }^{\text {Shell }}(n=9)$ mice. Scale bars: $B, 500 \mu \mathrm{m} ; \boldsymbol{C}, \boldsymbol{D}, 100 \mu \mathrm{m}$. ac, Anterior commissure. Data are shown as means \pm SEM.

alter the pavlovian conditioned approach nor did it restore cocaine sensitization. Either NAc ${ }^{\text {Core }}$ or NAc ${ }^{\text {Shell }}$ D1R expression stimulated instrumental responding for reward, but neither improved motivation to work for reward or motor learning.

\section{Materials and Methods}

Mice. The generation of mice with inactivation of Drdla by insertion of Cre recombinase were described previously (Heusner et al., 2008). $\mathrm{Drdla}{ }^{\mathrm{Cre} / \mathrm{Cre}}$ mice were generated by crossing heterozygous $\mathrm{Drdla} \mathrm{a}^{\mathrm{Cre} /+}$ mice and were born at the expected Mendelian ratio. An approximately equal number of male and female mice were used for all experiments. All experimental protocols were approved by the University of Washington Institutional Animal Care and Use Committee. Mice were housed on a 12:12 light:dark cycle and given ad libitum food and water except during food restriction to $85 \%$ of their ad libitum bodyweight.

Generation of AAV-FLEX-D1RGFP, viral injections, and experimental groups. The adeno-associated virus (AAV)-FLEX-D1RGFP was generated by PCR amplification of D1R from genomic DNA (C57BL/6J) using the primers 5'-GATATCACCGGTATGGCTCCTAACACTTCTAC-3' and 5 '-GATATCGCGGCCGCGGTTGAATGCTGTCCGCTGT- 3 '. The $1.3 \mathrm{~kb}$ PCR product was subcloned into AM/CBA-FLEX-EGFP-WPREbGH in-frame with EGFP. AAV was generated as described previously (Zweifel et al., 2008). For stereotaxic viral injections, $0.5 \mu \mathrm{l}$ of AAVFLEX-D1RGFP (titer $\sim 1 \times 10^{12} / \mathrm{ml}$ ) or control AAV-FLEX-GFP (titer $\left.\sim 1 \times 10^{12} / \mathrm{ml}\right)$ was bilaterally injected into the NAc ${ }^{\text {Core }}(x= \pm 1.0$, $\left.y=+1.3^{\star} \mathrm{F}, z=-4.25\right)$ or NAc ${ }^{\text {Shell }}\left(x= \pm 0.4, y=+1.3^{\star} \mathrm{F}, z=-5.0\right)$, $F=[$ lambda - bregma $] / 4.21$. To control for effects of site-specific injections and viral-mediated D1R expression in restricted NAc subregions, we generated the following experimental groups: NAc ${ }^{\text {Core }}$, Het GFP-NAc ${ }^{\text {Core }}$ $\left(\right.$ Drd $1 a^{\mathrm{Cre} /+}$; AAV-FLEX-GFP, NAc ${ }^{\text {Core }}$ injected); Het D1R-NAc ${ }^{\text {Core }}$ (Drd $1 a^{\mathrm{Cre} /+}$; AAV-FLEX-D1RGFP, NAc ${ }^{\text {Core }}$ injected); Mutant GFPNAc ${ }^{\text {Core }}\left(\right.$ Drd1a ${ }^{\text {Cre/Cre }}$; AAV-FLEX-GFP, NAc ${ }^{\text {Core }}$ injected); Mutant D1RNAc ${ }^{\text {Core }}\left(\right.$ Drd1 $a^{\text {Cre/Cre; }}$ AAV-FLEX-D1RGFP, NAc ${ }^{\text {Core }}$ injected). NAc ${ }^{\text {Shell, }}$,

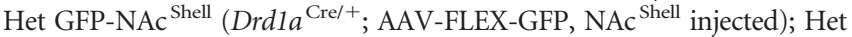
D1R-NAc ${ }^{\text {Shell }}$ (Drd1a ${ }^{\mathrm{Cre} /+}$; AAV-FLEX-D1RGFP, NAc ${ }^{\text {Shell }}$ injected); Mu-

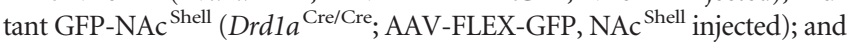
Mutant D1R-NAc ${ }^{\text {Shell }}\left(\right.$ Drd1a ${ }^{\text {Cre/Cre }}$; AAV-FLEX-D1RGFP, NAc ${ }^{\text {Shell }}$ injected). D1R-NAc ${ }^{\text {Core }}$ and D1R-NAc ${ }^{\text {Shell }}$ mice were compared with their 
respective heterozygous and mutant control groups. After surgery, mice recovered for 2 weeks before behavioral testing. Viral expression was confirmed with immunohistochemistry with the D1R antibody or with the GFP antibody that detected either GFP or D1RGFP.

Pavlovian conditioning. Training was performed in operant chambers (Med Associates) as described previously (Parker et al., 2010). Briefly, animals received daily pavlovian training for 7 days that included 25 trials per session. During each trial, two levers were presented for $10 \mathrm{~s}$, which co-terminated with a $20 \mathrm{mg}$ food pellet delivered noncontingently (Bioserve). Video tracking was performed with EthoVision (Noldus) on the final day to score lever or food receptacle contacts.

Instrumental conditioning. Four days of instrumental conditioning were performed with 50 trials per session in which a single lever press delivered a single food reward pellet. Food receptacle head entries were required to start the next trial. The session continued until 50 trials were completed or $2 \mathrm{~h}$ had elapsed. For progressive ratio testing, one reward pellet was delivered per completed trial in which the lever press requirement increased with a nonarithmetic schedule $(1,1,4,7,13,19,25,34$, $43,52,61,73 \ldots)$. The breakpoint was the last completed trial before 3 min of lever-pressing inactivity or a total $4 \mathrm{~h}$ session time-out.

Rotarod. Motor learning was measured on a rotarod (4-40 RPM over $2 \mathrm{~min}$ ) with 3 trials/d for $5 \mathrm{~d}$ (Columbus Instruments).

Pharmacology studies in locomotion chambers. For D1R agonist studies, SKF-81297 was administered intraperitoneally at $7.5 \mathrm{mg} / \mathrm{kg}$. Locomotor activity was measured for $90 \mathrm{~min}$ in locomotion chambers (Opto-M3; Columbus Instruments). For cocaine sensitization studies, baseline locomotion recordings were measured for $90 \mathrm{~min}$. For $2 \mathrm{~d}$, animals received injections of $0.9 \%$ saline, which were averaged. For the next $5 \mathrm{~d}$, cocaine was administered subcutaneously at $20 \mathrm{mg} / \mathrm{kg}$ and locomotor activity was measured for $90 \mathrm{~min}$.

Immunohistochemistry. For measuring c-Fos expression, $90 \mathrm{~min}$ before euthanasia and 4\% paraformaldehyde perfusion, animals received either $0.9 \%$ saline or $7.5 \mathrm{mg} / \mathrm{kg}$ SKF-81297. Then, $30 \mu \mathrm{m}$ frozen sections were collected between +1.1 to +1.5 (relative to bregma, A-P axis) and stained with the following primary antibodies: GFP, mouse monoclonal, 1:1000 (Invitrogen); c-Fos, rabbit polyclonal, 1:1000 (Calbiochem); D1R, rat monoclonal, 1:500 (Sigma-Aldrich); all secondary antibodies were 1:200 (Jackson ImmunoResearch). For c-Fos quantification, equal camera exposures were taken and c-Fos positive cells were counted with ImageJ software in three sections per animal at a defined ROI $(350 \times 500$ $\mu \mathrm{m}$ box centered on either the anterior commissure for the NAc Coreinjected groups or in the ventral medial portion of the NAc ${ }^{\text {Shell }}$ for the NAc Shell-injected groups). To measure the pattern of viral expression for D1R-NAc Core and D1R-NAc ${ }^{\text {Shell }}$ mice, Adobe Illustrator was used to trace the bilateral viral expression at the section closest to +1.3 (relative to bregma, A-P axis).

Statistical analyses. Data were analyzed using Excel (Microsoft) and MATLAB (MathWorks) software. Additional statistical calculations were performed in Prism software (GraphPad). All data were analyzed by two-way repeated-measures ANOVA or one-way ANOVA as indicated.

\section{Results}

\section{Functional restoration of D1R signaling in the NAc}

To establish our model system, we exclusively expressed D1R in either the $\mathrm{NAc}^{\mathrm{Core}}$ or the $\mathrm{NAc}^{\text {Shell }}$ using a mouse line in which D1R expression was functionally inactivated by inserting a Cre recombinase expression cassette into the open reading frame of the Drd1a locus (Heusner et al., 2008). This results in selective expression of Cre in D1R-containing cells. Mice homozygous for the Cre insertion are null mutants, Drdla ${ }^{\text {Cre/Cre }}$ (D1R mutants), and do not have detectable D1R protein levels (Fig. 1C,D). Similar to previously published D1R knock-out lines, D1R mutants generated by Cre insertion are indistinguishable from other D1R knock-out mouse lines (Drago et al., 1994, Xu et al., 1994). To re-express D1R in an anatomically restricted manner, we generated an AAV vector containing a Cre-conditional D1R-GFP expression cassette (AAV-FLEX-D1RGFP, Fig. 1A). D1R ex- pression restricted to either the NAc ${ }^{\text {Core }}\left(\mathrm{D} 1 \mathrm{R}-\mathrm{NAc}^{\mathrm{Core}}\right)$ or the NAc ${ }^{\text {Shell }}$ (D1R-NAc $\left.{ }^{\text {Shell }}\right)$ was achieved by bilateral stereotaxic injection of AAV-FLEX-D1RGFP into D1R mutants (Fig. 1C-F).

We next validated functional restoration of D1R in the NAc. D1R activation stimulates locomotor activity and dopamine signaling facilitates locomotor activation exclusively in the NAc (Swanson et al., 1997, Heusner et al., 2003). Therefore, to confirm D1R activation in D1R-NAc Core and D1R-NAc ${ }^{\text {Shell }}$ mice, we measured locomotor responses to systemic administration of the D1R agonist SKF-81297 (7.5 mg/kg). In the NAc Core groups, GFP-NAc ${ }^{\text {Core }}$ mutant mice $(n=7)$ displayed little locomotor response to the drug (Fig. 2A). In contrast, D1R-NAc ${ }^{\text {Core }}$ mice $(n=7)$ showed a strong agonist effect that was indistinguishable from that of heterozygous control groups (Het GFP-NAc Core, $n=7$; Het D1R-NAc ${ }^{\text {Core }}, n=8$; two-way repeated-measures ANOVA, genotype $\times$ time, $F_{(63,525)}=1.4, p=0.0282$; Fig. $2 A$ ). D1R-NAc ${ }^{\text {Shell }}(n=9)$ mice also responded to SKF-81297 with significantly increased locomotor activity compared with GFPNAc ${ }^{\text {Shell }}$ mutants $(n=7$; two-way repeated-measures ANOVA, genotype $\times$ time, $F_{(63,777)}=3.5, p<0.0001$; Fig. $2 B$ ), but did not respond as strongly as heterozygous control mice (Het GFPNAc ${ }^{\text {Shell }}, n=12$; Het D1R-NAc ${ }^{\text {Shell }}, n=13$; Fig. $2 B$ ).

To further confirm that signaling events downstream of D1R activation are present in D1R-NAc ${ }^{\text {Core }}$ and D1R-NAc ${ }^{\text {Shell }}$ mice, we quantified c-Fos expression around the area of viral restoration after SKF-81297 administration (7.5 mg/kg; Fig. 2C-F). D1R-NAc ${ }^{\text {Core }}(n=6)$ and control mice (Het GFP-NAc ${ }^{\text {Core }}, n=$ 5 ; Het D1R-NAc ${ }^{\text {Core }}, n=5$ ) showed robust c-Fos induction (one-way ANOVA, $F_{(4,25)}=12.2, p<0.0001$; Fig. $2 C$ ). In contrast, saline-injected controls (all genotypes, $n=8$ ) and SKF81297-treated GFP-NAc ${ }^{\text {Core }}$ mutants $(n=6)$ showed negligible c-Fos expression (Fig. 2E). Similarly, D1R-NAc ${ }^{\text {Shell }}(n=7)$ and control mice (Het GFP-NAc ${ }^{\text {Shell }}, n=10$; Het D1R-NAc ${ }^{\text {Shell }}, n=$ 10) also displayed strong induction of c-Fos compared with saline-injected controls (all genotypes, $n=9$ ) and SKF-81297treated GFP-NAc ${ }^{\text {Shell }}$ mutants $(n=6$; one-way ANOVA, $F_{(4,37)}=32.90, p<0.0001$; Fig. $\left.2 D, F\right)$. Therefore, re-expression of D1R to either the NAc ${ }^{\text {Core }}$ or the NAc ${ }^{\text {Shell }}$ can restore signaling and behavioral responsiveness to D1R agonist.

\section{Unique role of D1R in the NAc for pavlovian conditioning}

Having established the ability to regionally restrict expression of D1R to either the NAc Core or the NAc ${ }^{\text {Shell }}$, we next examined D1R in these regions for reward processing. In pavlovian conditioning, animals learn to associate a predictive cue with a reward outcome. These dopamine-dependent associations manifest behaviorally as conditioned approach to either the reward (goaltracking) or the predictive conditioned stimulus (CS) cue (signtracking) (Flagel et al., 2011). To determine whether D1R in the NAc is sufficient for pavlovian conditioning, we trained mice to associate a reward-predictive cue ( $10 \mathrm{~s}$ lever extension) with food pellet delivery. In mice, conditioned approach typically manifests as goal-tracking (Parker et al., 2010) measured by calculating the difference between the head entry rate during the CS presentation and the intertrial interval. In contrast to heterozygous control mice in the NAc ${ }^{\text {Core }}$ group (Het GFP-NAc ${ }^{\text {Core }}, n=8$; Het D1RNAc ${ }^{\text {Core }}, n=8$ ), we did not find the head entry rate in D1RNAc ${ }^{\text {Core }}$ mice $(n=7)$ to be significantly above their respective mutant control group (GFP-NAc ${ }^{\text {Core }}, n=7$ ) during CS presentation (two-way repeated-measures ANOVA, genotype $\times$ time, $F_{(18,156)}=1.87, p=0.0222$; Fig. 3A). Similarly, D1R-NAc ${ }^{\text {Shell }}$ mice $(n=9)$ also failed to increase their head entry rate significantly above respective mutant controls (GFP-NAc ${ }^{\text {Shell }}, n=7$; 
A

NAC Core

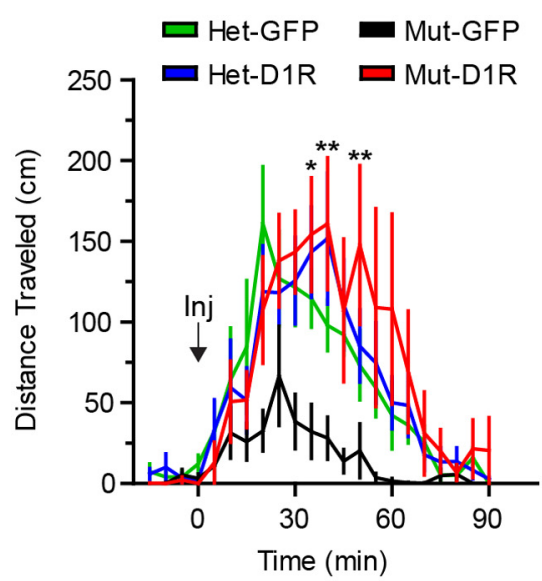

C
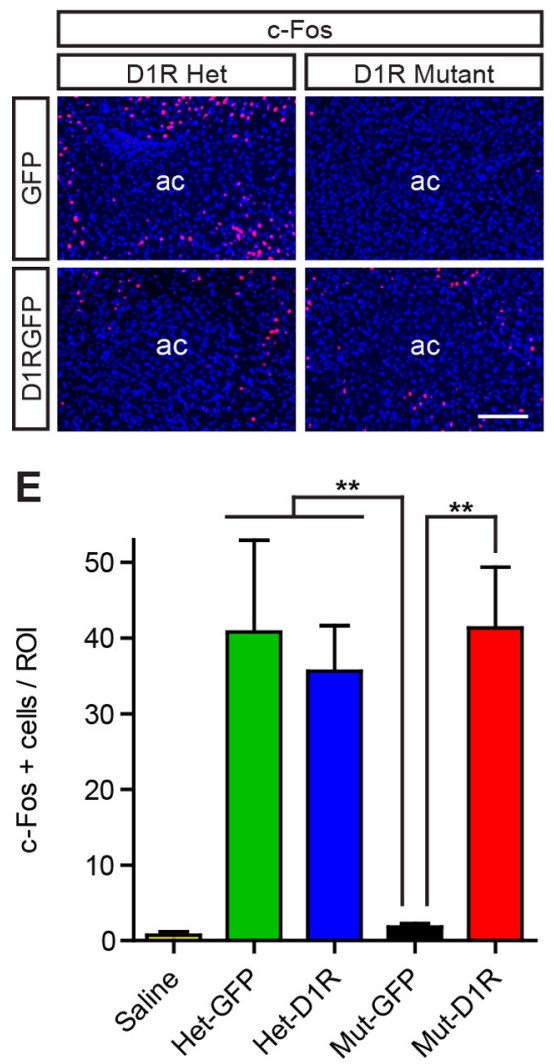

B

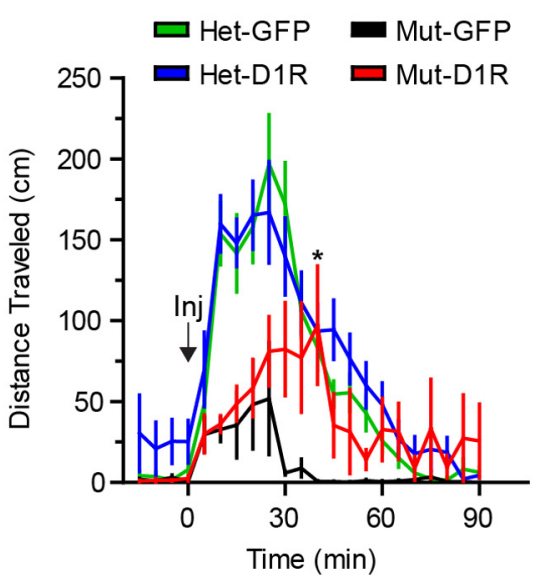

D

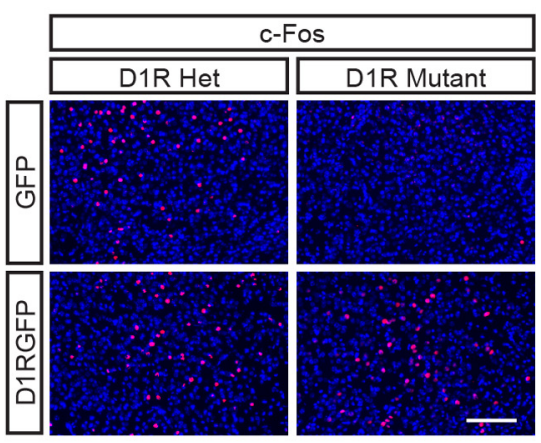

$\mathbf{F}$

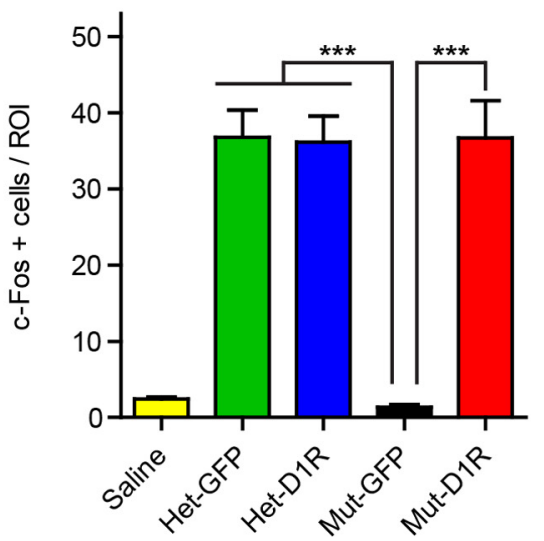

Figure 2. $D 1 R$ in either the NAC ${ }^{\text {Core }}$ or the NAC Shell restores behavioral responsiveness and functional D1R signaling. $A, B$, Locomotor response to the D1 agonist SKF-81297 in NAC ${ }^{\text {Core }}$ and NAc ${ }^{\text {Shell }}$ mice (NAC ${ }^{\text {Core }}$ : Het-GFP, $n=7 ;$ Het-D1R, $n=8$; Mut-GFP, $n=7$; Mut-D1R, $n=7$; NAC ${ }^{\text {Shell. }}$ Het-GFP, $n=12$; Het-D1R, $n=13$; Mut-GFP, $n=7 ;$ Mut-D1R, $\left.n=9\right) . C, D$, SKF-81297 induced c-Fos expression (red) in D1R-NAC ${ }^{\text {Core }}$ (Mut-D1R) and control mice and D1R-NAc ${ }^{\text {Shell }}$ (Mut-D1R) and control mice. Brain sections were counterstained with Hoechst (blue). $\boldsymbol{E}, \boldsymbol{F}$, Quantification of c-Fos-positive cells in NAc ${ }^{\text {Core }}$ and NAc ${ }^{\text {Shell }}$ mice (NAc ${ }^{\text {Core. }}$ :

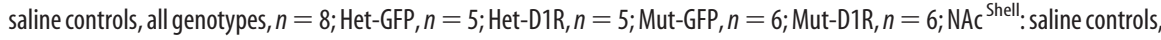
all genotypes, $n=9$; Het-GFP, $n=10$; Het-D1R, $n=10$; Mut-GFP, $n=6$; Mut-D1R, $n=7$ ). $\boldsymbol{A}$, $\boldsymbol{B}$, Bonferroni's multiplecomparison test, ${ }^{*} p<0.05,{ }^{* *} p<0.01$ for D1R-NAc ${ }^{\text {Core }}$ or D1R-NAc ${ }^{\text {Shell }}$ mice versus D1R mutants, respectively. $\boldsymbol{E}, \boldsymbol{F}$, Tukey's multiple-comparison test, ${ }^{* *} p<0.01,{ }^{* *} p<0.001$ for D1R mutants versus all other groups. Scale bars, $100 \mu \mathrm{m}$. Data are shown as means \pm SEM.

Fig. 3B). Intriguingly, while viewing the animals during conditioning, we observed D1R-NAc ${ }^{\text {Core }}$ mice (Fig. $3 C$ ), but not D1RNAc ${ }^{\text {Shell }}$ mice (Fig. 3D), exhibiting a heightened approach behavior in which they repeatedly shuttled between the food receptacle and levers, a behavior undetected by strictly measuring

head entries. To quantify this behavior, on the final day of conditioning, we videotaped each trial $(25$ total $)$ and scored conditioned approach to the food receptacle, lever, or both (Fig. 3E,F). We found that GFPNAc ${ }^{\text {Core }}$ and GFP-NAc ${ }^{\text {Shell }}$ mutant mice made significantly fewer conditioned approaches compared with their respective heterozygous controls (Fig. 3E,F). However, DIR-NAc ${ }^{\text {Core }}$ mice exhibited conditioned approaches to the food receptacle, lever, or both (one-way ANOVA, $F_{(3,26)}=$ $19.68, p<0.0001 ;$ Fig. $3 E$ ). In very few trials did control or D1R-NAc ${ }^{\text {Core }}$ mice solely approach the lever, indicating that they were not exclusively sign-tracking, but rather performing a hybrid goal-tracking/sign tracking behavior. D1R-NAc ${ }^{\text {Shell }}$ mice did not display this behavior (oneway ANOVA, $F_{(3,38)}=113.1, p<$ 0.0001; Fig. 3F).

\section{Sufficiency of D1R in the NAc for instrumental conditioning}

Conditioned approach to the lever by

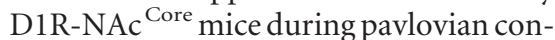
ditioning suggests that these animals have assigned some value to the cue, so we investigated whether they would perform an instrumental response (lever press) to acquire reward. Immediately after pavlovian conditioning, mice were given a simple, fixed ratio schedule of one lever press for one reward pellet. As reported previously (El-Ghundi et al., 2003, Caine et al., 2007, Wall et al., 2011), D1R null mice (GFP-NAc ${ }^{\text {Core }}$ mutant, $n=7$ ) were severely deficient in this task relative to heterozygous controls (Het GFP-NAc ${ }^{\text {Core }} n=8$; Het D1R-NAc ${ }^{\text {Core }}, n=8$; Fig. $4 A$ ). Remarkably, the performance of D1R-NAc Core mice $(n=7)$ was significantly more robust than that of GFP-NAc ${ }^{\text {Core }}$ mutants ( $n=7$; two-way repeated-measures ANOVA, genotype $\times$ time, $F_{(9,78)}=$ $4.11, p=0.0002$; Fig. $4 A$ ). Surprisingly, despite previously displaying no pavlovian conditioned approach behavior to the levers, D1R-NAc ${ }^{\text {Shell }}$ mice $(n=9)$ also displayed significantly increased instrumental responding relative to their respective mutant controls (GFP-NAc ${ }^{\text {shell }}$ mutant, $n=7$; two-way repeatedmeasures ANOVA, effect of genotype, $F_{(3,38)}=14.20, p<0.0001$; effect of time, $F_{(3,114)}=7.24, p=0.0002$; Fig. $\left.4 B\right)$. Furthermore, cumulative reward acquisition in both D1R-NAc ${ }^{\text {Core }}$ and D1R-NAc ${ }^{\text {Shell }}$ mice revealed that both groups completed or nearly completed all lever presses (NAc ${ }^{\text {Core }}$ experiment: two-way repeated-measures ANOVA, genotype $\times$ time, $F_{(720,6240)}=4.33, p<0.0001$; Fig. $4 C$; NAc ${ }^{\text {Shell }}$ experiment: 
two-way repeated-measures ANOVA, genotype $\times$ time, $F_{(720,9120)}=8.97, p<$ 0.0001; Fig. 4D).

The improved performance of D1RNAc ${ }^{\text {core }}$ and D1R-NAc ${ }^{\text {Shell }}$ mice in instrumental behavior compared with mutant mice suggests that these animals are capable of performing an action required to attain reward. To determine whether their enhanced instrumental performance reflects an increased incentive to perform work, we tested mice in a progressive ratio task that measured the animal's breakpoint to an escalating increase in lever presses required to deliver a single reward pellet. Both D1R-NAc ${ }^{\text {Core }}$ and D1RNAc ${ }^{\text {Shell }}$ mice showed a marginal yet statistically insignificant increase in breakpoint compared with D1R mutants (Fig. 4E,F). However, D1R-NAc ${ }^{\text {Core }}$,

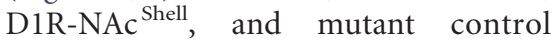
breakpoints were significantly smaller compared with heterozygous control mice (NAc $^{\text {Core }}$ experiment: one-way ANOVA, $F_{(3,12)}=7.029, p=0.0055$; Fig. $4 E$; NAc ${ }^{\text {Shell }}$ experiment: one-way ANOVA, $F_{(3,38)}=$ 16.96, $p<0.0001$; Fig. $4 F$ ). Thus, although D1R-NAc ${ }^{\text {Core }}$ and D1R-NAc ${ }^{\text {Shell }}$ mice could perform a simple fixed ratio task when challenged with escalating costs to obtain reward, they failed to perform at the level of controls.

To determine whether instrumental performance by D1R-NAc core and D1RNAc ${ }^{\text {Shell }}$ mice simply reflects improved motor coordination, we assayed mice in a rotarod task. Similar to mutants (GFPNAc ${ }^{\text {Core }}, n=7$; GFP-NAc ${ }^{\text {Shell }}, n=7$ ), both D1R-NAc Core $(n=7)$ and D1R$\mathrm{NAc}^{\text {Shell }}(n=9)$ mice failed to improve over $5 \mathrm{~d}$ of training and performed significantly worse than their respective heterozygous controls (NAc Core experiment: Het GFP-NAc ${ }^{\text {Core }}, n=8$; Het D1R-NAc ${ }^{\text {Core }}$, $n=8$; two-way repeated-measures ANOVA, genotype $\times$ time, $F_{(12,104)}=2.47$, $p=0.0071$; Fig. 5A; NAc Shell experiment: Het GFP-NAc ${ }^{\text {Shell }}, n=13$; Het D1RNAc Shell, $n=13$; two-way repeated-measures ANOVA, genotype $\times$ time, $F_{(12,152)}=$ $3.70, p<0.0001$; Fig. $5 B$ ). Therefore, D1R in either the NAc ${ }^{\text {Core }}$ or the NAc ${ }^{\text {Shell }}$ can facilitate instrumental performance despite the inability to improve motor coordination, indicating a dissociable minimal requirement of D1R for these behaviors.
A

NAc ${ }^{\text {Core }}$

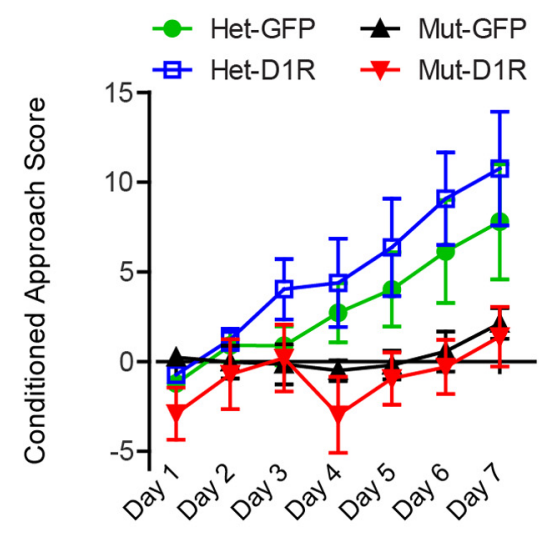

C
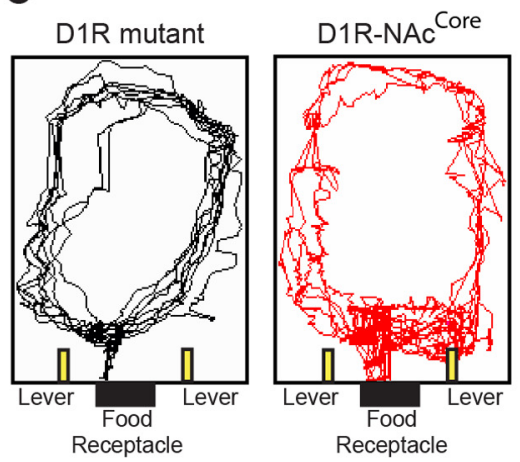

E
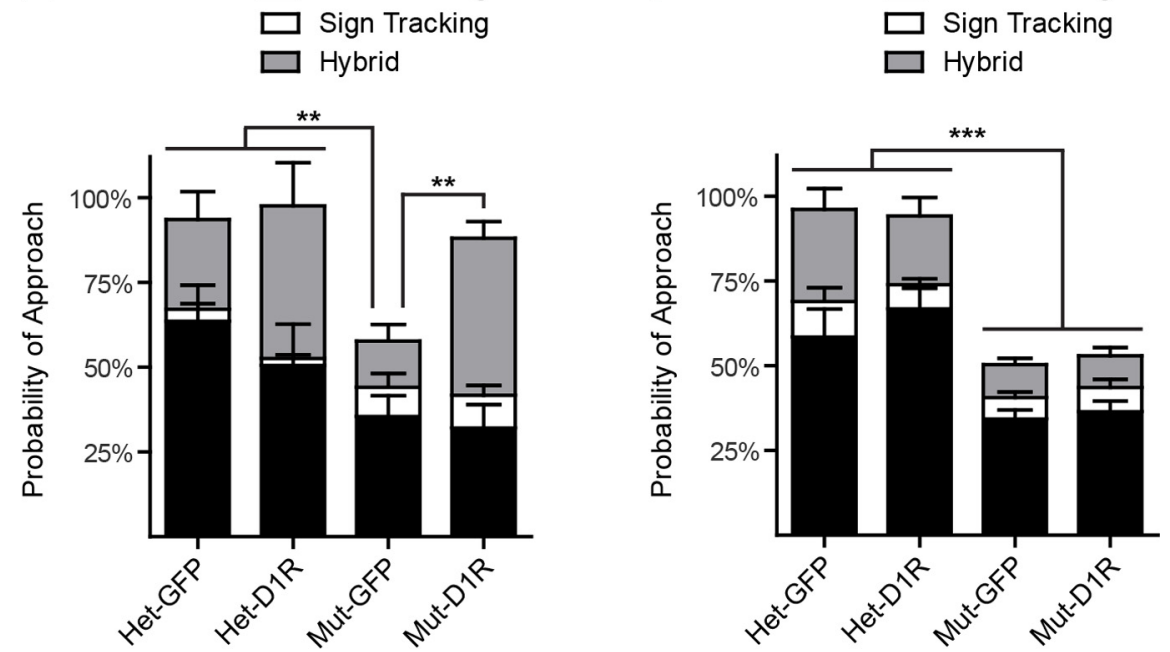

Figure 3. D1R in the $N A C^{\text {Core }}$, but not the NAC ${ }^{\text {Shell }}$, facilitates pavlovian conditioned approach behavior. $A, B$, Pavlovian conditioned approach score, [(CS head entry rate) - (intertrial interval head entry rate)] for NAC ${ }^{\text {Core }}$ and NAC ${ }^{\text {Core }}$ mice (NAC ${ }^{\text {Core. }}$ Het-GFP, $n=8$; Het-D1R, $n=8$; Mut-GFP, $n=7$; Mut-D1R, $n=7$; NAc Shell: Het-GFP, $n=13$; Het-D1R, $n=13$; Mut-GFP, $n=$ 7; Mut-D1R, $n=9$ ). $C$, $\boldsymbol{D}$, Track tracing from last trial of day 7 for D1R mutant and D1R-NAC ${ }^{\text {Core }}$ mice and D1R mutant and D1R-NAC ${ }^{\text {Shell }}$ mice illustrating conditioned approach to the lever and receptacle in D1R-NAC ${ }^{\text {Core }}$ mice, but not in the mutant control groups or D1R-NAC ${ }^{\text {Shell }}$ mice. $E, F$, Quantification of conditioned approach behavior for NAC ${ }^{\text {Core }}$ and NAC ${ }^{\text {Shell }}$ mice from $A, B . E, F$, Tukey's multiple-comparison test, ${ }^{* *} p<0.01,{ }^{* * *} p<0.001$. Data are shown as means \pm SEM.

\section{Differential minimal requirement of D1R in the NAc ${ }^{\text {Core }}$ and NAc ${ }^{\text {Shell }}$ for cocaine sensitization}

The ability to assign value to cues or actions requires neuroplastic changes in the NAc that depends upon D1R signaling (Kelley, 2004). Drugs of abuse usurp this endogenous reward system, leading to escalated incentive value for the drug, which can be observed as psychomotor sensitization to repeated drug administration (Robinson and Berridge, 2008). To determine whether D1R in either the NAc ${ }^{\text {Core }}$ or the NAc ${ }^{\text {Shell }}$ is sufficient to mediate behavioral adaptation to elevated synaptic dopamine levels associated with repeated drug exposure, we measured locomotor sensitization in response to daily cocaine injections (Fig. 6A-D). 
A

NAc Core
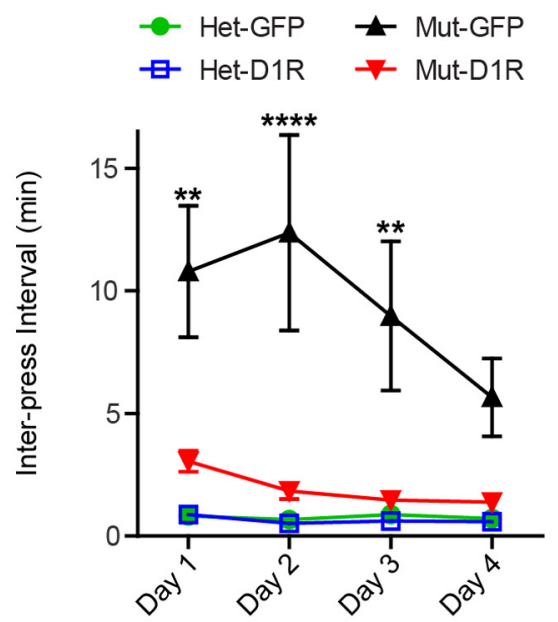

C

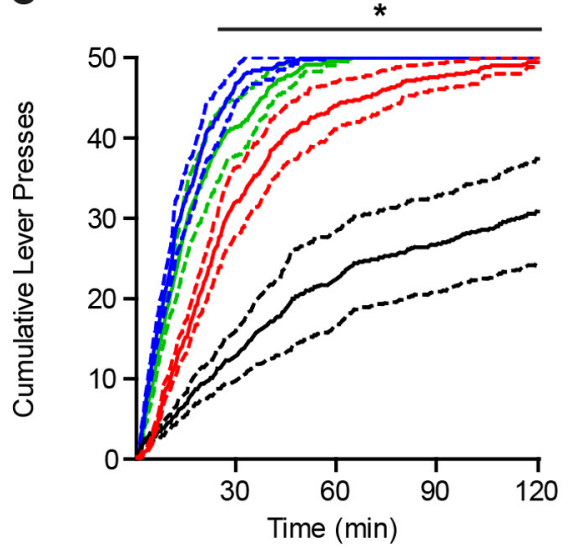

E

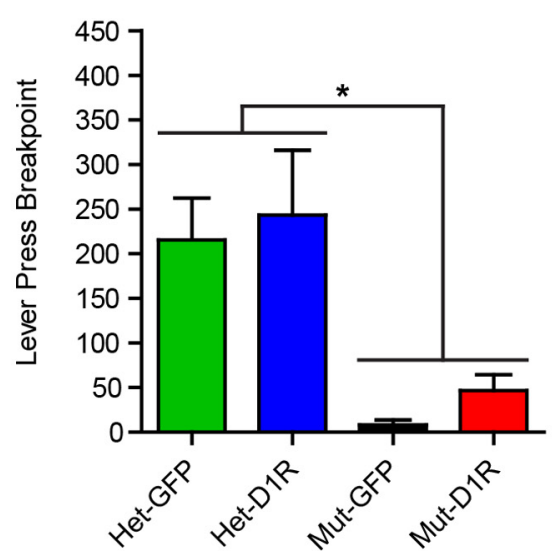

B
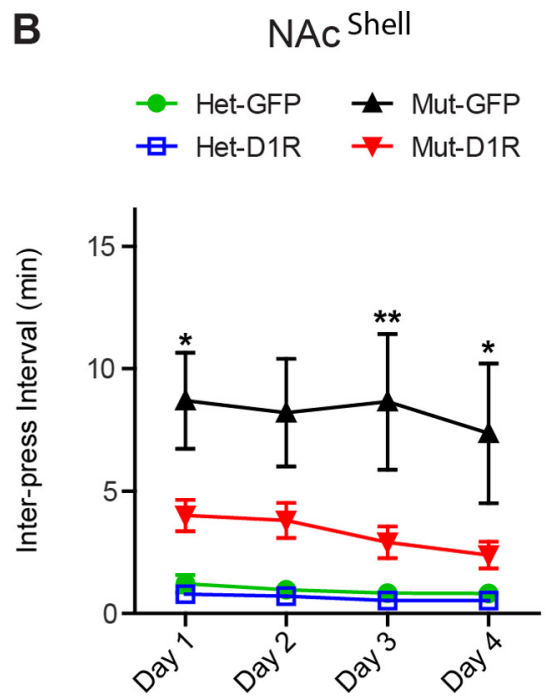

D

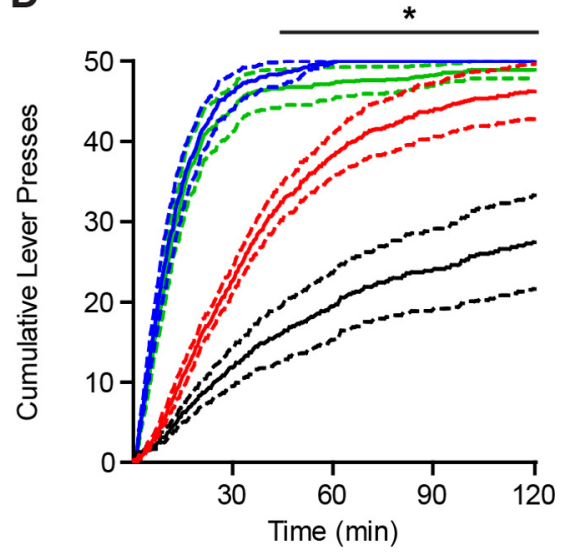

F

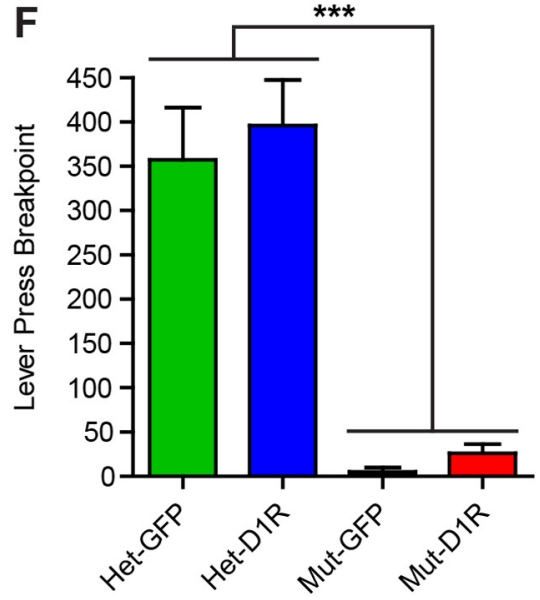

Figure 4. D1R in either the NAC ${ }^{\text {Core }}$ or the NAC ${ }^{\text {Shell }}$ promotes instrumental conditioning. $A, B$, Interpress interval during instrumental conditioning over $4 \mathrm{~d}$ for NAc ${ }^{\text {core }}$ and NAc ${ }^{\text {Shell }}$ mice (NAc ${ }^{\text {Core. }}$ : Het-GFP, $n=8$; Het-D1R, $n=8$; Mut-GFP, $n=7 ;$ Mut-D1R, $n=7$; NAc ${ }^{\text {Shell: }}$ Het-GFP, $n=13$; Het-D1R, $n=13$; Mut-GFP, $n=7 ;$ Mut-D1R, $n=9$ ). $\boldsymbol{C}, \boldsymbol{D}$, Cumulative lever presses on day 4 for $N A c^{C o r e}$ and NAC ${ }^{\text {Shell }}$ mice from $\boldsymbol{A}, \boldsymbol{B}$. E, $\boldsymbol{F}$, Progressive ratio breakpoint analysis for NAC ${ }^{\text {Core }}$ and NAC ${ }^{\text {Shell }}$ mice (NAC ${ }^{{ }^{C o r e}}$ : Het-GFP,

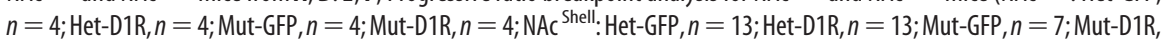
$n=9)$. $\boldsymbol{A}-\boldsymbol{D}$, Bonferroni's multiple-comparison test, ${ }^{*} p<0.05,{ }^{* *} p<0.01,{ }^{* * * *} p<0.0001$ for D1R-NAc ${ }^{\text {Core }}$ or D1R-NAc ${ }^{\text {Shell }}$ mice versus D1R mutants, respectively. $\boldsymbol{E}, \boldsymbol{F}$, Tukey's multiple-comparison test, ${ }^{*} p<0.05,{ }^{* * *} p<0.001$ for D1R mutants versus all other groups. Data are shown as means \pm SEM.

Locomotor activity was monitored for 90 min before cocaine administration (20 $\mathrm{mg} / \mathrm{kg}$ ) and then for an additional $90 \mathrm{~min}$ (Fig. $6 A, B$ ). After $5 \mathrm{~d}$ of cocaine injections in the NAc ${ }^{\text {Core }}$ mice, both D1R-NAc Core $(n=7)$ and heterozygous control mice (Het GFP-NAc ${ }^{\text {Core }}, n=7$; Het D1RNAc $\left.{ }^{\text {Core }}, n=8\right)$ robustly sensitized, which was not observed in mutant control mice (GFP-NAc ${ }^{\text {Core }}$ mutant, $n=7$; twoway repeated-measures ANOVA, genotype $\times$ time, $F_{(105,875)}=4.10, p<0.0001$; Fig. 6C). In contrast to D1R-NAc Core mice, D1R-NAc ${ }^{\text {Shell }}$ animals $(n=9)$ failed to show acute responses or locomotor sensitization to cocaine; however, their respective heterozygous controls showed robust sensitization (Het GFP-NAc Shell, $n=12$; Het D1R-NAc ${ }^{\text {Shell }}, n=13$; twoway repeated-measures ANOVA, genotype $\times$ time, $F_{(105,1295)}=9.40, p<0.0001$; Fig. $6 D$ ). Intriguingly, D1R-NAc ${ }^{\text {Core }}$, D1RNAc Shell, and mutant controls showed hyper-novelty responses during the first 90 min of habituation to the locomotion chambers, indicating that D1R in neither the NAc ${ }^{\text {Core }}$ nor the NAc ${ }^{\text {Shell }}$ is sufficient to reverse this behavioral phenotype (Fig. 6A$D)$. To account for this hyperactivity, we normalized cumulative cocaine responses by subtracting the first $90 \mathrm{~min}$ from the last 90 min of activity, which further highlighted locomotor sensitization to cocaine in D1R-NAc ${ }^{\text {Core }}$, but not D1R-NAc ${ }^{\text {Shell }}$ mice (NAc ${ }^{\text {Core }}$ experiment: two-way repeatedmeasures ANOVA, genotype $\times$ time, $F_{(15,125)}=2.67, p=0.0015$; Fig. $6 E ;$ NAc Shell experiment: two-way repeated-measures ANOVA, genotype $\times$ time, $F_{(15,185)}=2.09$, $p=0.0121$; Fig. $6 F$ ).

\section{Discussion}

Defining the minimal requirements for genes expressed within a neural circuit is essential to understanding how circuits regulate different dimensions of behavior. Studying minimal gene requirements within a specific circuit node can be achieved using different strategies. For example, nonconditional viral vectors can be injected into a region of interest in a conventional global knock-out (Carlezon et al., 1997), but this yields ectopic expression in cells that do not endogenously express the gene. In contrast, select promoters can drive more specific expression from a viral vector (Ferguson et al., 2011), but the minimal promoter is frequently too large for efficient viral packaging. Alternatively, using the approach described here, the endogenous gene locus drives Cre expression and simultaneously creates a global knock-out. Therefore, conditional viral vectors can be introduced 

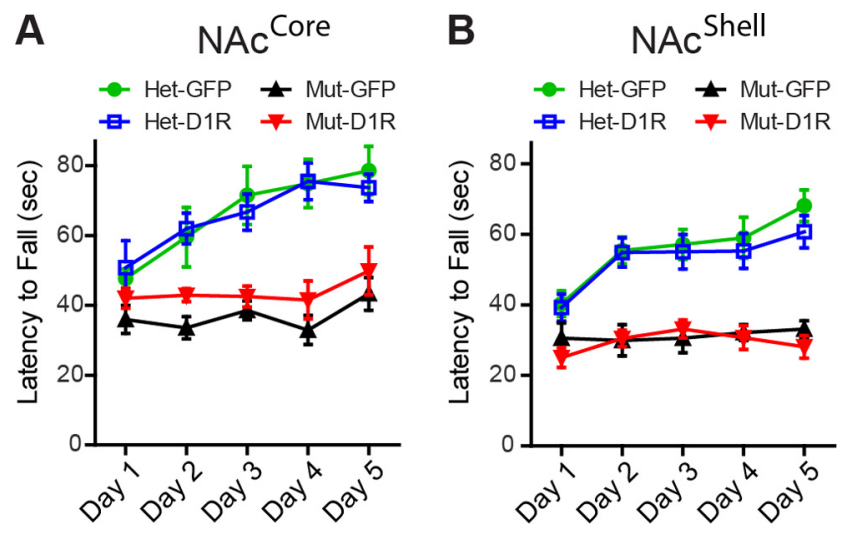

Figure 5. D1R in neither the NAC ${ }^{\text {Core }}$ nor the NAC Shell improves rotarod performance. $\boldsymbol{A}, \boldsymbol{B}$, Average latency to fall during 3 trials/d of rotarod testing over $5 \mathrm{~d}$. Neither D1R-NAc ${ }^{\text {Core }}$ nor D1R-NAc ${ }^{\text {Shell }}$ mice demonstrated significant improvement relative to mutant control groups (NAC ${ }^{\text {Core. }}$ Het-GFP, $n=8$; Het-D1R, $n=8$; Mut-GFP, $n=7$; Mut-D1R, $n=7$; NAc ${ }^{\text {Shell: }}$ Het-GFP, $n=13$; Het-D1R, $n=13$; Mut-GFP, $n=7$; Mut-D1R, $n=9)$. Data are shown as means \pm SEM.

into select regions to re-express the gene only in cells endogenously expressing the gene. Numerous Cre-knock-in lines have been generated, so this approach will prove broadly useful for studying minimal gene requirements.

Using this strategy, we show here that functional D1R signaling can be regenerated in an anatomically restricted and cellselective manner. This is illustrated by restoring locomotor activation and the induction of c-Fos in response to the D1R agonist SKF-81297. Although these results are consistent with functional re-expression of D1R, without ultrastructural analysis, we cannot unequivocally establish that the protein is precisely targeted to the endogenous location within the cell or that levels are not excessive. However, immunolocalization of recombinant D1R in both D1R-NAc core and D1R-NAc ${ }^{\text {Shell }}$ mice demonstrated the protein was largely localized to neural processes, remarkably similar to staining of the endogenous protein in heterozygous control mice. In addition, AAV-FLEX-D1RGFP delivered to the NAc ${ }^{\text {Core }}$ or the NAc ${ }^{\text {Shell }}$ of heterozygous mice did not significantly alter behavior, indicating that expression does not perturb endogenous receptor function. Although D1RGFP in the NAc ${ }^{\text {Core }}$ of heterozygous mice shifted these animals toward more hybrid tracking behavior during pavlovian conditioning, this was not statistically significant (this is discussed further below).

Systemic administration of D1R agonist induced locomotion in both D1R-NAc ${ }^{\text {Core }}$ and D1R-NAc ${ }^{\text {Shell }}$ mice. These results are consistent with a previously published study showing that restoration of dopamine to the NAc ${ }^{\text {Core }}$ in dopamine-deficient animals was sufficient to promote psychomotor activation by amphetamine, an effect blocked by D1- and D2-type receptor antagonists (Heusner et al., 2003). Furthermore, infusing dopamine into either the NAc ${ }^{\text {Core }}$ or the NAc ${ }^{\text {Shell }}$ potentiates locomotor activity (Swanson et al., 1997), but in contrast to our findings, the study showed infusing the D1R agonist had a greater effect in the NAc ${ }^{\text {Shell }}$. Our results demonstrate that D1R-dependent behavioral sensitization to cocaine can be mediated exclusively by D1R activation in the NAc ${ }^{\text {Core }}$, but not the NAc ${ }^{\text {Shell }}$. Previous studies have reported that repeated cocaine administration enhances D1R sensitivity of NAc neurons (White et al., 1993) and increases dopamine release in both the NAc ${ }^{\text {Core }}$ and the NAc ${ }^{\text {Shell }}$ (Addy et al., 2010). Glutamate plasticity within the NAc ${ }^{\text {Core }}$ after repeated cocaine has also been reported and proposed to be de- pendent on D1R (Pierce et al., 1996). In contrast to our results, repeated cocaine administration has been shown to enhance sen-

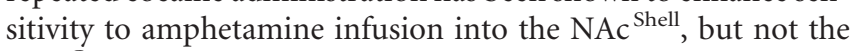
NAc ${ }^{\text {Core }}$. This effect was observed after long-term, but not shortterm, withdrawal; however, early acquisition of sensitized responses was not investigated (Pierce and Kalivas, 1995). Temporal differences in electrophysiological changes (Kourrich and Thomas, 2009) and morphological changes (Dumitriu et al., 2012) have been found between the NAc ${ }^{\text {Core }}$ and the NAc ${ }^{\text {Shell }}$ after cocaine sensitization, suggesting independent functions of these brain regions acting over different time courses for discrete facets of drug-related behavior. Consistent with this, D1R signaling in the NAc ${ }^{\text {Core }}$ and the NAc ${ }^{\text {Shell }}$ is essential for distinct aspects of drug self-administration (Anderson et al., 2003, Bachtell et al., 2005, Bari and Pierce, 2005, Schmidt et al., 2006, Bossert et al., 2007, Laviolette et al., 2008, Shin et al., 2008, Suto and Wise, 2011), so future experiments with combined viral restoration in both the NAc ${ }^{\text {Core }}$ and the NAc ${ }^{\text {Shell }}$ during various stages of drug seeking will help to address this important question. We should also note that D1R antagonists infused into the prefrontal cortex can block cocaine sensitization (Sorg et al., 2001). One potential explanation for the apparent necessity of D1R in one scenario but not another is the D5 receptor, which is also inhibited by D1R antagonists and is highly expressed in the prefrontal cortex (Oda et al., 2010). Consistent with this, locomotor responding to cocaine has been shown to be attenuated dose dependently in D5R knock-out mice (Elliot et al., 2003); however, others have not reported similar findings (Karlsson et al., 2008). Finally, although it is possible that developmental compensatory changes occur in D1R mutants, allowing a smaller subset of D1R-expressing brain regions to be minimally sufficient, this is unlikely because reexpression of D1R in the NAc ${ }^{\text {Shell }}$ did not facilitate all behaviors restored by D1R in the NAc ${ }^{\text {Core }}$.

Restricted expression of D1R in the NAc Core reveals additional insight into the circuit level requirement for D1R during appetitive pavlovian conditioning. The NAc ${ }^{\text {Core }}$ is conventionally associated with preparatory pavlovian conditioned approach (Flagel et al., 2011), CS-unconditioned stimulus associations during conditioned reinforcement (Parkinson et al., 1999), and the generalized form of pavlovian-Instrumental transfer (Corbit and Balleine, 2011). We were initially surprised that D1RNAc Core animals failed to demonstrate "normal" conditioned approach behavior typically observed in mice. Instead, we observed a hybrid goal/sign-tracking conditioned approach. Mice almost exclusively exhibit goal-tracking conditioned approach behavior, as evidenced by Het GFP-NAc ${ }^{\text {Core }}$ mice that predominantly approached the food receptacle exclusively. In contrast to mice, rats show individual preference to either goal or signtracking, but importantly, only sign-tracking (not goal-tracking) is sensitive to the broad spectrum dopamine receptor antagonist flupenthixol (Flagel et al., 2011) and sign-tracking rats have higher levels of D1R in the NAc (Flagel et al., 2007). We found that exclusive expression of D1R in the NAc ${ }^{\text {Core }}$ promoted the highest degree of conditioned approaches to the lever, with Het D1R-NAc ${ }^{\text {Core }}$ mice displaying a more intermediate level of hybrid tracking. These results indicate that restoring D1R selectively to the NAc ${ }^{\text {Core }}$ potentially overrides an innate goal-tracking preference in mice. In addition, sign-tracking in rats is associated with enhanced sensitization to drugs of abuse (Flagel et al., 2010) and, consistent with this, we found that D1R-NAc ${ }^{\text {Core }}$ mice had the highest levels of sensitization, further supporting the link among NAc Core $\mathrm{D} 1 \mathrm{R}$, sign-tracking, and drug sensitization. These results suggest that shifting the balance of D1R activation in the brain more heavily 
A

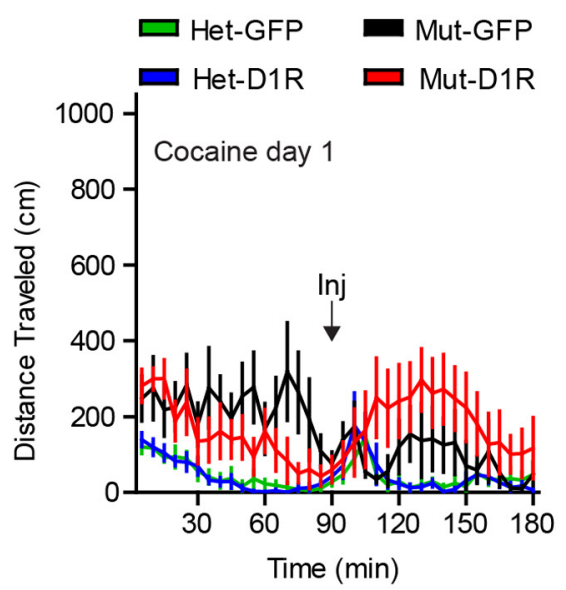

C
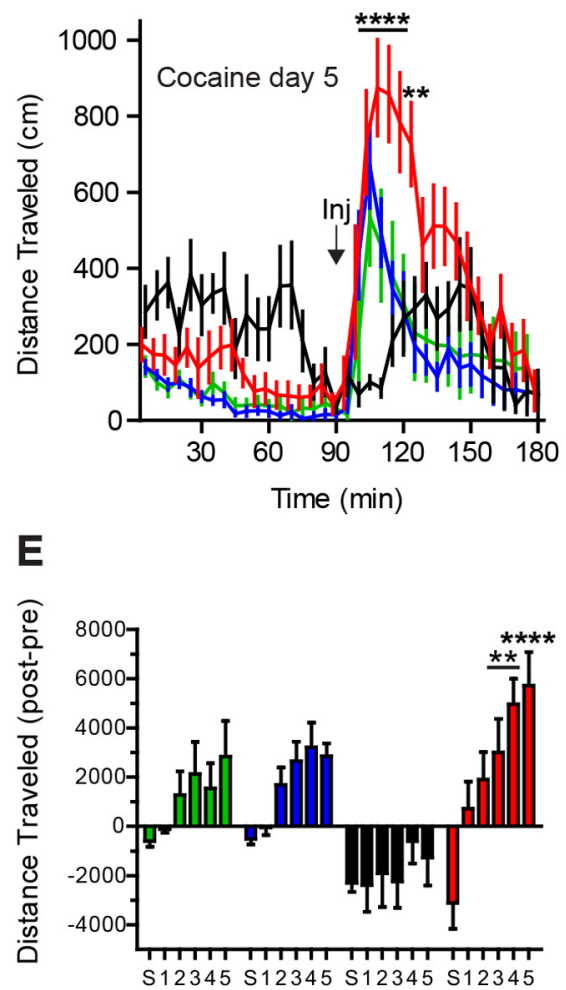

B

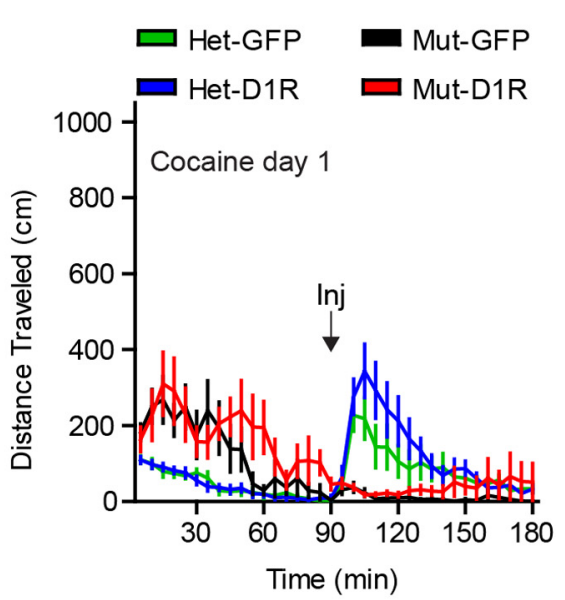

D

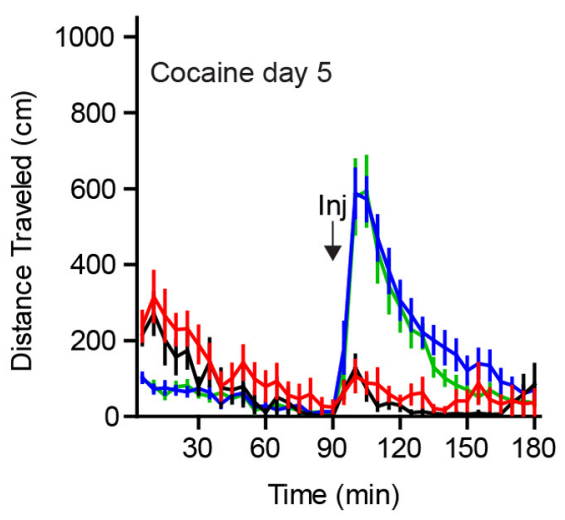

F

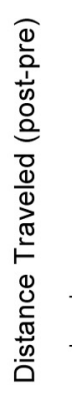

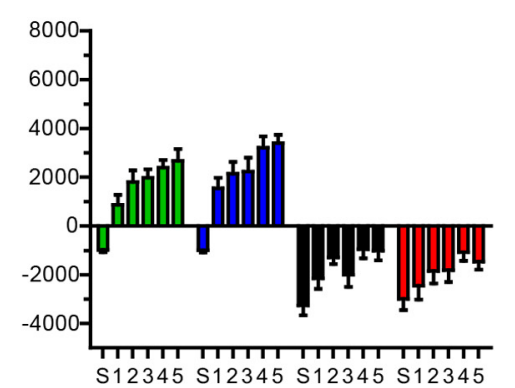

Figure 6. D1R in the NAC ${ }^{\text {Core }}$, but not the NAC ${ }^{\text {Shell }}$, is sufficient for locomotor sensitization to cocaine. $A, B$, Locomotor response to cocaine on day 1 for NAc ${ }^{\text {Core }}$ and NAc ${ }^{\text {Shell }}$ mice (NAC ${ }^{\text {Core. }}$ Het-GFP, $n=7$; Het-D1R, $n=8$; Mut-GFP, $n=7$;

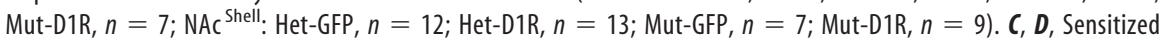
locomotor response to cocaine on day 5 for D1R-NAC ${ }^{\text {core }}$, but not D1R-NAc Shell , mice. $E, F$, Normalized cumulative locomotor activity, [90 min postinjection period] - [90 min baseline preinjection period] for saline $(S)$ and $5 \mathrm{~d}$ of cocaine. $\boldsymbol{C}, \boldsymbol{E}$, Bonferroni's multiple-comparison test, ${ }^{* *} p<0.01,{ }^{* * * *} p<0.0001$ for D1R-NAc ${ }^{\text {Core }}$ or D1R-NAc ${ }^{\text {Shell }}$ mice versus D1R mutants. Data are shown as means \pm SEM.

toward, or exclusively to, the NAc ${ }^{\text {Core }}$, shifts behavior toward signtracking, a conditioned approach strategy more sensitive to dopamine levels and associated with enhanced behavioral responding to drugs of abuse.

The development of instrumental responding in D1RNAc ${ }^{\text {Core }}$ and D1R-NAc ${ }^{\text {Shell }}$ mice is consistent with these animals assigning value to the lever to perform simple action-outcome responses. Although both groups responded significantly better than mutant control mice, they may have done so through different mechanisms. D1R-NAc Core mice demonstrated condi-

tioned approach to the levers, suggesting that they assigned incentive salience to the levers, possibly strengthening the actionoutcome association required in the subsequent instrumental conditioning sessions. This is consistent with observations that suppression of excitatory inputs to the NAcCore from the amygdala impairs cued reward retrieval and activation of this projection facilitates instrumental responding, which is blocked by systemic administration of D1R antagonists (Stuber et al., 2011). In contrast, D1R-NAc ${ }^{\text {Shell }}$ mice demonstrated instrumental performance despite their lack of pavlovian conditioned approach, suggesting that D1R-NAc ${ }^{\text {Shell }}$ mice have elevated instrumental responding through a different mechanism compared with D1RNAc ${ }^{\text {Core }}$ mice. This is consistent with these animals having restored consummatory or hedonic processes (Yin et al., 2008) sufficient for action-outcome responding, but lacking the ability to form conditioned reward associations. Intriguingly, although D1R-NAc ${ }^{\text {Core }}$ and D1R-NAc ${ }^{\text {Shell }}$ mice performed the simple instrumental response, they demonstrated profound motivational deficits to work for reward. These results suggest dissociable circuit requirements for performing tasks when costs are low versus high. One explanation for this finding is that a lack of D1R expression in other brain regions could make these mice more sensitive to extinction and/or contingency changes during a progressive ratio task. For example, these mice lack D1R in the prefrontal cortex, hippocampus, and amygdala, all structures known to be necessary for cost-benefit decision making (Floresco et al., 2008). In addition, dorsal striatum D1R signaling is necessary for habit formation (Lovinger, 2010), so the lack of D1R in the dorsal striatum of D1R-NAc ${ }^{\text {Core }}$ or D1R-NAc ${ }^{\text {Shell }}$ mice may prevent transforming goal-directed actions into habitual responses.

Failure of D1R-NAc Core and D1RNAc ${ }^{\text {Shell }}$ mice to improve motor coordination and attenuate novelty-induced hyperactivity further highlights the selective nature of D1R function in circuits underlying distinct dopaminedependent behaviors. Therefore, our model allows for the systematic determination of the minimal requirements of D1R signaling in discrete brain regions to establish functional D1R-dependent circuit maps underlying dopamine-dependent behaviors. Establishing functional maps of where gene expression is minimally required to mediate specific functions is essential for therapeutic approaches requiring targeted intervention. Our approach provides a critical first step in establishing a method to define the minimal requirements for $\mathrm{D} 1 \mathrm{R}$ in regulating complex behavior. Therefore, future experiments to define the minimal requirements of $\mathrm{D} 1 \mathrm{R}$ for other behaviors will be es- 
sential for understanding the neural circuitry underlying dopamine-dependent processes and disease.

\section{References}

Addy NA, Daberkow DP, Ford JN, Garris PA, Wightman RM (2010) Sensitization of rapid dopamine signaling in the nucleus accumbens core and shell after repeated cocaine in rats. J Neurophysiol 104:922-931. CrossRef Medline

Anderson SM, Bari AA, Pierce RC (2003) Administration of the D1-like dopamine receptor antagonist SCH-23390 into the medial nucleus accumbens shell attenuates cocaine priming-induced reinstatement of drug-seeking behavior in rats. Psychopharmacology 168:132-138. CrossRef Medline

Bachtell RK, Whisler K, Karanian D, Self DW (2005) Effects of intra-nucleus accumbens shell administration of dopamine agonists and antagonists on cocaine-taking and cocaine-seeking behaviors in the rat. Psychopharmacology 183:41-53. CrossRef Medline

Baldwin AE, Sadeghian K, Kelley AE (2002) Appetitive instrumental learning requires coincident activation of NMDA and dopamine D1 receptors within the medial prefrontal cortex. J Neurosci 22:1063-1071. Medline

Bari AA, Pierce RC (2005) D1-like and D2 dopamine receptor antagonists administered into the shell subregion of the rat nucleus accumbens decrease cocaine, but not food, reinforcement. Neuroscience 135:959-968. CrossRef Medline

Berglind WJ, Case JM, Parker MP, Fuchs RA, See RE (2006) Dopamine D1 or D2 receptor antagonism within the basolateral amygdala differentially alters the acquisition of cocaine-cue associations necessary for cueinduced reinstatement of cocaine-seeking. Neuroscience 137:699-706. CrossRef Medline

Beutler LR, Wanat MJ, Quintana A, Sanz E, Bamford NS, Zweifel LS, Palmiter RD (2011) Balanced NMDA receptor activity in dopamine D1 receptor (D1R)- and D2R-expressing medium spiny neurons is required for amphetamine sensitization. Proc Natl Acad Sci U S A 108:4206-4211. CrossRef Medline

Bossert JM, Poles GC, Wihbey KA, Koya E, Shaham Y (2007) Differential effects of blockade of dopamine D1-family receptors in nucleus accumbens core or shell on reinstatement of heroin seeking induced by contextual and discrete cues. J Neurosci 27:12655-12663. CrossRef Medline

Caine SB, Thomsen M, Gabriel KI, Berkowitz JS, Gold LH, Koob GF, Tonegawa S, Zhang J, Xu M (2007) Lack of self-administration of cocaine in dopamine D1 receptor knock-out mice. J Neurosci 27:13140-13150. CrossRef Medline

Carlezon WA Jr, Boundy VA, Haile CN, Lane SB, Kalb RG, Neve RL, Nestler EJ (1997) Sensitization to morphine induced by viral-mediated gene transfer. Science 277:812-814. CrossRef Medline

Corbit LH, Balleine BW (2011) The general and outcome-specific forms of pavlovian-instrumental transfer are differentially mediated by the nucleus accumbens core and shell. J Neurosci 31:11786-11794. CrossRef Medline

Drago J, Gerfen CR, Lachowicz JE, Steiner H, Hollon TR, Love PE, Ooi GT, Grinberg A, Lee EJ, Huang SP (1994) Altered striatal function in a mutant mouse lacking D1A dopamine receptors. Proc Natl Acad Sci U S A 91:12564-12568. CrossRef Medline

Dumitriu D, Laplant Q, Grossman YS, Dias C, Janssen WG, Russo SJ, Morrison JH, Nestler EJ (2012) Subregional, dendritic compartment, and spine subtype specificity in cocaine regulation of dendritic spines in the nucleus accumbens. J Neurosci 32:6957-6966. CrossRef Medline

El-Ghundi M, O’Dowd BF, Erclik M, George SR (2003) Attenuation of sucrose reinforcement in dopamine D1 receptor deficient mice. Eur J Neurosci 17:851-862. CrossRef Medline

Elliot EE, Sibley DR, Katz JL (2003) Locomotor and discriminativestimulus effects of cocaine in dopamine D5 receptor knock-out mice. Psychopharmacology 169:161-168. CrossRef Medline

Ferguson SM, Eskenazi D, Ishikawa M, Wanat MJ, Phillips PE, Dong Y, Roth BL, Neumaier JF (2011) Transient neuronal inhibition reveals opposing roles of indirect and direct pathways in sensitization. Nat Neurosci 14:22-24. CrossRef Medline

Flagel SB, Watson SJ, Robinson TE, Akil H (2007) Individual differences in the propensity to approach signals vs goals promote different adaptations in the dopamine system of rats. Psychopharmacology 191:599-607. CrossRef Medline

Flagel SB, Robinson TE, Clark JJ, Clinton SM, Watson SJ, Seeman P, Phillips
PE, Akil H (2010) An animal model of genetic vulnerability to behavioral disinhibition and responsiveness to reward-related cues: implications for addiction. Neuropsychopharmacology 35:388-400. CrossRef Medline

Flagel SB, Clark JJ, Robinson TE, Mayo L, Czuj A, Willuhn I, Akers CA, Clinton SM, Phillips PE, Akil H (2011) A selective role for dopamine in stimulus-reward learning. Nature 469:53-57. CrossRef Medline

Floresco SB, St Onge JR, Ghods-Sharifi S, Winstanley CA (2008) Corticolimbic-striatal circuits subserving different forms of cost-benefit decision making. Cogn Aff Behav Neurosci 8:375-389. CrossRef Medline

Franklin KJB, Paxions G (2007) The mouse brain in stereotaxic coordinates, Ed 3. San Diego, CA: Academic.

Heusner CL, Hnasko TS, Szczypka MS, Liu Y, During MJ, Palmiter RD (2003) Viral restoration of dopamine to the nucleus accumbens is sufficient to induce a locomotor response to amphetamine. Brain Res 980: 266-274. CrossRef Medline

Heusner CL, Beutler LR, Houser CR, Palmiter RD (2008) Deletion of GAD67 in dopamine receptor-1 expressing cells causes specific motor deficits. Genesis 46:357-367. CrossRef Medline

Karlsson RM, Hefner KR, Sibley DR, Holmes A (2008) Comparison of dopamine D1 and D5 receptor knockout mice for cocaine locomotor sensitization. Psychopharmacology 200:117-127. CrossRef Medline

Kelley AE (2004) Memory and addiction: shared neural circuitry and molecular mechanisms. Neuron 44:161-179. CrossRef Medline

Kourrich S, Thomas MJ (2009) Similar neurons, opposite adaptations: psychostimulant experience differentially alters firing properties in accumbens core versus shell. J Neurosci 29:12275-12283. CrossRef Medline

Laviolette SR, Lauzon NM, Bishop SF, Sun N, Tan H (2008) Dopamine signaling through D1-like versus D2-like receptors in the nucleus accumbens core versus shell differentially modulates nicotine reward sensitivity. J Neurosci 28:8025-8033. CrossRef Medline

Lobo MK, Covington HE 3rd, Chaudhury D, Friedman AK, Sun H, DamezWerno D, Dietz DM, Zaman S, Koo JW, Kennedy PJ, Mouzon E, Mogri M, Neve RL, Deisseroth K, Han MH, Nestler EJ (2010) Cell type-specific loss of BDNF signaling mimics optogenetic control of cocaine reward. Science 330:385-390. CrossRef Medline

Lovinger DM (2010) Neurotransmitter roles in synaptic modulation, plasticity and learning in the dorsal striatum. Neuropharmacology 58:951-961. CrossRef Medline

Oda S, Funato H, Adachi-Akahane S, Ito M, Okada A, Igarashi H, Yokofujita J, Kuroda M (2010) Dopamine D5 receptor immunoreactivity is differentially distributed in GABAergic interneurons and pyramidal cells in the rat medial prefrontal cortex. Brain Res 1329:89-102. CrossRef Medline

Parker JG, Zweifel LS, Clark JJ, Evans SB, Phillips PE, Palmiter RD (2010) Absence of NMDA receptors in dopamine neurons attenuates dopamine release but not conditioned approach during Pavlovian conditioning. Proc Natl Acad Sci U S A 107:13491-13496. CrossRef Medline

Parkinson JA, Olmstead MC, Burns LH, Robbins TW, Everitt BJ (1999) Dissociation in effects of lesions of the nucleus accumbens core and shell on appetitive pavlovian approach behavior and the potentiation of conditioned reinforcement and locomotor activity by D-amphetamine. J Neurosci 19:2401-2411. Medline

Pierce RC, Kalivas PW (1995) Amphetamine produces sensitized increases in locomotion and extracellular dopamine preferentially in the nucleus accumbens shell of rats administered repeated cocaine. J Pharmacol Exp Ther 275:1019-1029. Medline

Pierce RC, Bell K, Duffy P, Kalivas PW (1996) Repeated cocaine augments excitatory amino acid transmission in the nucleus accumbens only in rats having developed behavioral sensitization. J Neurosci 16:1550-1560. Medline

Robinson TE, Berridge KC (2008) The incentive sensitization theory of addiction: some current issues. Philos Trans R Soc Lond B Biol Sci 363: 3137-3146. CrossRef Medline

Salamone JD, Correa M, Nunes EJ, Randall PA, Pardo M (2012) The behavioral pharmacology of effort-related choice behavior: dopamine, adenosine and beyond. J Exp Anal Behav 97:125-146. CrossRef Medline

Schmidt HD, Anderson SM, Pierce RC (2006) Stimulation of D1-like or D2 dopamine receptors in the shell, but not the core, of the nucleus accumbens reinstates cocaine-seeking behaviour in the rat. Eur J Neurosci 23: 219-228. CrossRef Medline

Shin R, Qin M, Liu ZH, Ikemoto S (2008) Intracranial self-administration of MDMA into the ventral striatum of the rat: differential roles of the 
nucleus accumbens shell, core, and olfactory tubercle. Psychopharmacology 198:261-270. CrossRef Medline

Smith-Roe SL, Kelley AE (2000) Coincident activation of NMDA and dopamine D1 receptors within the nucleus accumbens core is required for appetitive instrumental learning. J Neurosci 20:7737-7742. Medline

Sorg BA, Li N, Wu WR (2001) Dopamine D1 receptor activation in the medial prefrontal cortex prevents the expression of cocaine sensitization. J Pharmacol Exp Ther 297:501-508. Medline

Stuber GD, Sparta DR, Stamatakis AM, van Leeuwen WA, Hardjoprajitno JE, Cho S, Tye KM, Kempadoo KA, Zhang F, Deisseroth K, Bonci A (2011) Excitatory transmission from the amygdala to nucleus accumbens facilitates reward seeking. Nature 475:377-380. CrossRef Medline

Suto N, Wise RA (2011) Satiating effects of cocaine are controlled by dopamine actions in the nucleus accumbens core. J Neurosci 31:17917-17922. CrossRef Medline

Swanson CJ, Heath S, Stratford TR, Kelley AE (1997) Differential behavioral responses to dopaminergic stimulation of nucleus accumbens subregions in the rat. Pharmacol Biochem Behav 58:933-945. CrossRef Medline

Tye KM, Tye LD, Cone JJ, Hekkelman EF, Janak PH, Bonci A (2010) Meth- ylphenidate facilitates learning-induced amygdala plasticity. Nat Neurosci 13:475-481. CrossRef Medline

Wall VZ, Parker JG, Fadok JP, Darvas M, Zweifel L, Palmiter RD (2011) A behavioral genetics approach to understanding D1 receptor involvement in phasic dopamine signaling. Mol Cell Neurosci 46:21-31. CrossRef Medline

White FJ, Hu XT, Henry DJ (1993) Electrophysiological effects of cocaine in the rat nucleus accumbens: microiontophoretic studies. J Pharmacol Exp Ther 266:1075-1084. Medline

Xu M, Moratalla R, Gold LH, Hiroi N, Koob GF, Graybiel AM, Tonegawa S (1994) Dopamine D1 receptor mutant mice are deficient in striatal expression of dynorphin and in dopamine-mediated behavioral responses. Cell 79:729-742. CrossRef Medline

Yin HH, Ostlund SB, Balleine BW (2008) Reward-guided learning beyond dopamine in the nucleus accumbens: the integrative functions of corticobasal ganglia networks. Eur J Neurosci 28:1437-1448. CrossRef Medline

Zweifel LS, Argilli E, Bonci A, Palmiter RD (2008) Role of NMDA receptors in dopamine neurons for plasticity and addictive behaviors. Neuron 59: 486-496. CrossRef Medline 